\title{
Pulmonary Valve Atresia
}

National Cancer Institute

\section{Source}

National Cancer Institute. Pulmonary Valve Atresia. NCI Thesaurus. Code C99031.

A cong enital heart defect characterized by complete atresia of the pulmonary valve. It is manifested during infancy with cyanosis, dyspnea, and tachypnea. 